\title{
Influence of MWCNTs on the Mechanical Properties of Continuous Carbon Epoxy Composites
}

\author{
Jyothhi Yarlagaddaa, Ramakrishna Malkapuram*
}

Department of Mechanical Engineering, Vignan's Foundation for Science, Technology and Research, Vadlamudi, Guntur, 522213, India

Corresponding Author Email: dean_iqac@vignan.ac.in

https://doi.org/10.18280/rcma.300106

Received: 17 September 2019

Accepted: 9 November 2019

\section{Keywords:}

multi walled carbon nanotubes, ultrasonicator, drum winding, hand lay up, continous carbon fibre reinforced epoxy

\begin{abstract}
The Carbon fiber reinforced epoxy composites finds wide range of applications in various fields such as aerospace, defence etc. The present study focuses on fabrication and mechanical characterization of different ply oriented Continuous Carbon Fibre reinforcedepoxy composites (CCFE). CCFE composites were fabricated using Drum winding, Hand Lay Up (HLU) followed by Compression Moulding with $\left(0^{\circ}\right) 4$, $\left(0^{\circ} / 90^{\circ} / 0^{\circ} / 90^{\circ}\right) 4,\left(45^{\circ}\right) 4$ orientations. Mechanical Characterisation was performed on the fabricated composites as per ASTM standards. CCFE with $\left(0^{\circ} / 90^{\circ} / 0^{\circ} / 90^{\circ}\right)_{4}$ orientation exhibited better compressive strength over other composites. $0.5,1.5$ weight $\%$ of Multi Walled Carbon Nano-Tubes (MWCNTs) were reinforced in to the epoxy resin using ultrasonicator. The resin mixture with $0.5,1.5$ weight $\%$ of MWCNTs was used as matrix for the fabrication of $\left(0^{\circ} / 90^{\circ} / 0^{\circ} / 90^{\circ}\right)_{4}$ composites. Tensile, Compression, Flexural, Impact, Hardness and Water absorption tests were performed to investigate the effect of MWCNTs on $\left(0^{\circ} / 90^{\circ} / 0^{\circ} / 90^{\circ}\right)_{4}$ composites. CCFE samples with MWCNTs at $0.5 \%$ exhibited $1.63 \%, 5.23 \%, 16.47 \%, 3.9 \%, 29.6 \%$ increment in tensile strength, compressive strength, ILSS, impact strength, hardness, water absorptionand $36.9 \%$ decrement in flexural strength.
\end{abstract}

\section{INTRODUCTION}

The application of Carbon fibre/epoxy composite materials is spread over in many fields such as aerospace, aviation, windpower, and electronic equipment because of their high strength to weight ratio and specific modulus [1]. Matrix transfers the load very effectively to the Carbon fibres according to interface transfer theory, there by stressing the importance of interfacial properties while restricting the applications of that particular composite [2, 3]. Interfacial interaction between carbon fibre and epoxy influences the mechanical properties of carbon fibre reinforced epoxy composites [4]. Composite laminated structures mostly fail due to weak interface between fibre and matrix resulting in delamination [5]. The interfacial adhesion of polymer fibre composites was strengthened by incorporation of Nanoreinforcements into the matrix or on the fibre surface. The emerging Nano materials were fullerene, carbon nanotubes (CNTs), graphene and their derivatives [6-12]. CNTs were outstanding candidates for fabricating high polymer Nano composites due to their low density, larger aspect ratio, excellent mechanical, thermal and electrical properties [13]. CNTs were introduced on to the carbon fibre surface through electrophoretic deposition and low-temperature growth [14, 15]. The interface between carbon fibre and epoxy polymer can be enhanced by the addition of CNTs due to the interlocking of epoxy and the surface of carbon fibre [16]. Addition of $0.5 \%$ CNT to epoxy based CFRP composites results in better flexural strength and modulus, $12 \%$ increase in ILSS, $17 \%, 19.5 \%$ increase in torsional modulus and strength when compared to neat CFRP composites [17]. Carbon fibre reinforced-grapheme oxide reinforced hybrid epoxy composites exhibit good mechanical properties at 0.3 weight $\%$ of GO, because of the higher surface area of Nano size GO, which aids in good bonding between matrix and reinforcement [18]. Continuous carbon fibre epoxy composites incorporated with $\mathrm{HHal}$ and $\mathrm{SiCW}$ possess $2 \%$ higher densities than those composites incorporated with MWCNT, due to the relatively high densities of HHal and $\mathrm{SiCW}$. The flexural strength of the composites increased with the addition of all the three fillers, but the continuous carbon fibre epoxy composites with MWCNT showed good increment due to the better penetration of the filler into the lamina because of their relatively low size when compared to $\mathrm{HHal}$ and SiCW. Addition of MWCNT to continuous carbon fibre epoxy composites exhibit $25 \%$ increase in strength, $11 \%$ increase in modulus, and $14 \%$ decrease in ductility when compared to unmodified composites $[19,20]$. There is increase of $6 \%-8 \%$ stiffness and strength between neat and carbon nano fibre (CNF) reinforced laminates because of the presence of proper bonding between $\mathrm{CNF}$ and matrix whichfacilitates in transfer of strain energy from the fibres during elastic deformation [21].

The present study focuses on the effect of MWCNTs on the mechanical properties of $0 \% / 90^{\circ} / 0^{\circ} / 90^{\circ}$ ply oriented carbon fibre epoxy Nano composites. 


\section{MATERIALS AND METHODS}

\subsection{Materials}

Commercially available Continuous Carbon Fibre Roving TC-35 12K was procured from - Jalark Carbon Products, Gujarat, India. Multi walled Carbon Nanotubes (MWCNT) with OD as $10-30 \mathrm{~nm}$ and length as $1-10 \mu \mathrm{m}$ and $90 \%$ purity were procured from Nano Wings Private Limited, R\&D centre, Khammam, Telangana, India. Epoxy with trade name ARALDYTE LY 556 and hardener with trade name HY556 were procured from MS Industries, Kakinada, Andhra Pradesh, India. HY556 type hardener and Araldite-LY951 type epoxy were mixed in the ratio of 1:10.

\subsection{Methods}

Continuous Carbon fibre spools were placed at Creel stand, one end of the fibre from the spool is immersed into the resin tank which is attached to the drum winding machine. The cylindrical sheet obtained by drum winding is cut to mould dimensions and arranged at different fibre ply orientations (FPO's) followed by compression moulding in hydraulic Press at $150^{\circ} \mathrm{C}$ for 3 hours. Applying resin to the mould and placing the fibre layer by layer along with consolidation and ramming followed by Compression moulding at $150^{\circ} \mathrm{C}$ for 3 hours. CNT reinforced carbon fibre epoxy composites were fabricated by incorporating CNT in to the epoxy resin using ultrasonicator. The process is repeated by incorporating 0.5 wt $\%, 1.5 \mathrm{wt} \% \mathrm{CNT}$ in $\left(0^{\circ} / 90^{\circ} / 0^{\circ} / 90^{\circ}\right)_{4}$ orientation. The experimental arrangement of drum winding are shown in Figure 1 and Figure 2.

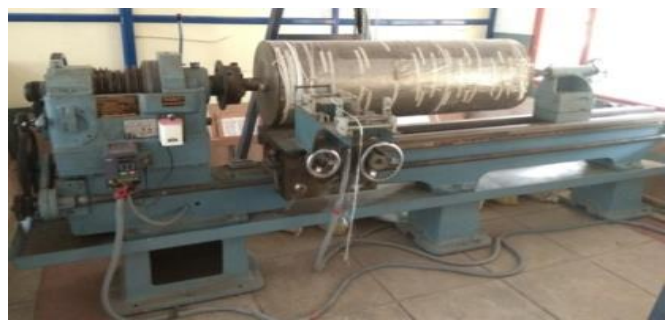

Figure 1. Drum winding equipment
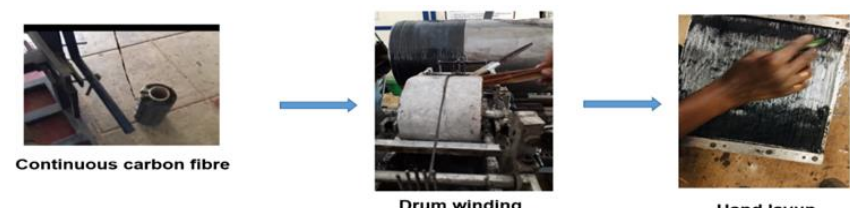

Hand layup

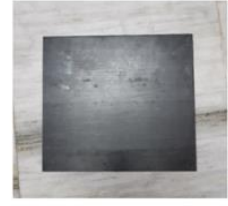

CCFIEpoxy laminate

Compression molding

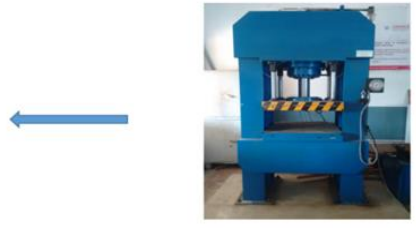

Figure 2. Flow chart of sample preparation

Mechanical characterisation was performed on the fabricated CNT/carbon fibre epoxy composites. Tensile and compressive properties of the samples were measured on Adithya UTM equipment (model UTE - 40KN, shown in Figure 3(a) in accordance with ASTMD3039 and ASTM D695.
The dimensions of the specimens tested for tensile properties were approximately (thickness $\times$ width $\times$ gauge length) $3 \times 25$ $\times 250 \mathrm{~mm}$ and a span length of $150 \mathrm{~mm}$ and for compressive properties were approximately $3 \times 12.7 \times 25.4 \mathrm{~mm}$ with a cross head travel of $2 \mathrm{~mm} / \mathrm{min}$. Flexural and ILSS tests of the samples were performed on United UTM (model STM-50KN, shown in Figure3(b) as per ASTM D790 and ASTM D2344 standards. The dimensions of the specimens tested for flexural properties were approximately (thickness $\times$ width $\times$ gauge length) $3 \times 10 \times 50 \mathrm{~mm}$ and for ILSS were approximately 3 $\times 10 \times 90 \mathrm{~mm}$. At least five specimens of each composite were tested. Izod impact strength of notched samples was tested on a KI-1.4 instrument, as shown in Figure 3 (c) according to ASTM D256. The dimensions of the specimens tested were approximately $3.2 \times 12.7 \times 64 \mathrm{~mm}$ at ambient conditions, i.e at a temperature of $23^{\circ} \mathrm{C}$ and a relative humidity of $40 \%$, the measurements were performed. The impact energy was divided by the width of the specimens to yield impact strength $(\mathrm{J} / \mathrm{m})$. At least five specimens of each composite were tested. Shore D hardness of the samples were determined in accordance with ASTM D 2240 standard using durometer. The test measures the penetration of a specified indenter into the material under specified conditions of force and time. Samples of approximate dimensions $3 \times 25.4 \times 76.2$ (thickness $\times$ width $\times$ length) were used for themeasurements of water absorption as per ASTM D 570. After being vacuum-dried at $70^{\circ} \mathrm{C}$ to a constant weight, the specimens are immersed in distilled water at ambient temperature. The specimens were takenout of the water after 24, 48 and 72 hours respectively, surface dried with absorbent paper, reweighed and immediately put back into the water. Water absorption is calculated according to the formula.

$$
\text { Water absorption } \%=\frac{\text { Wet weight }- \text { Initial weight }}{\text { Initial weight }} \times 100
$$

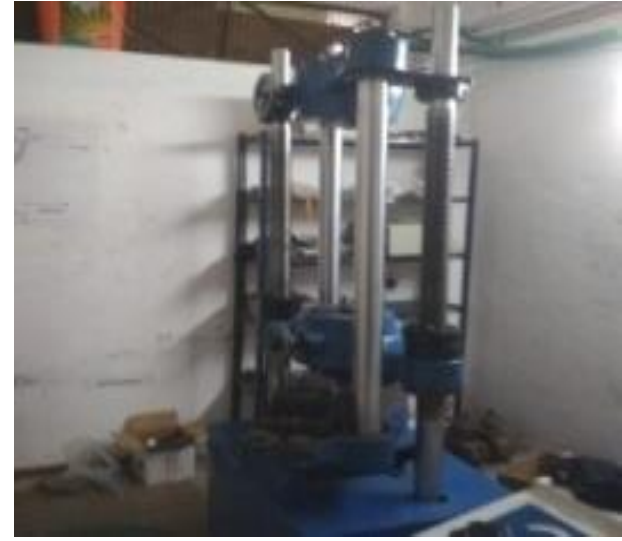

3(a) UTM -Tensile and compressive test equipment

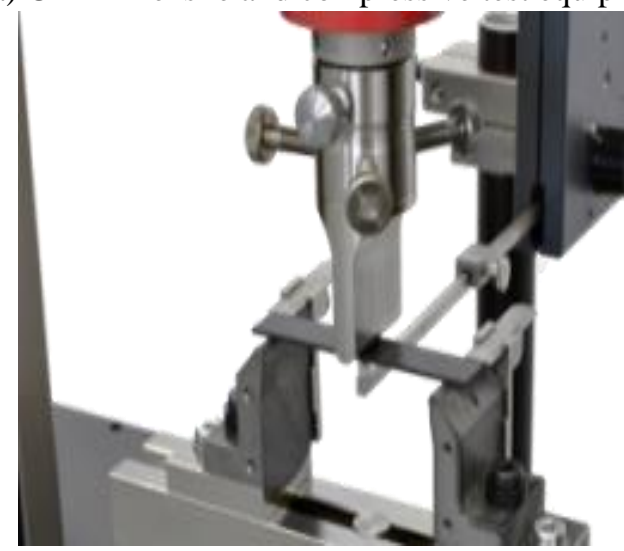

3(b) Flexural test equipment 


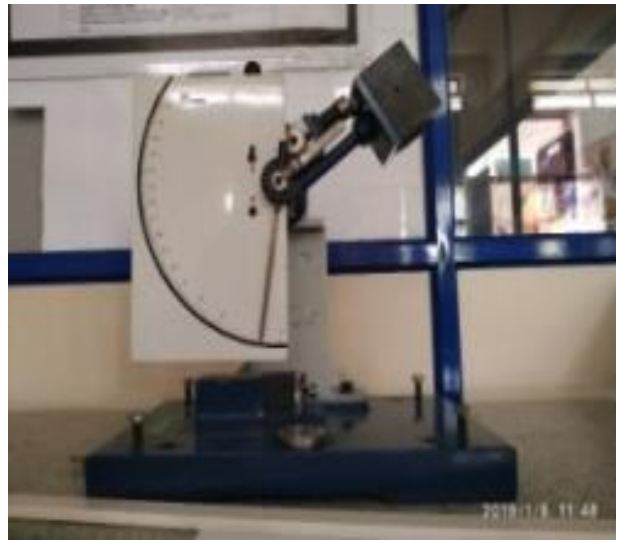

3(c) Impact test equipment

Figure 3. Experimental setup of tensile, compression, flexural and impact tests

\section{RESULTS AND DISCUSSION}

\subsection{Tensile properties}

The tensile properties of CNT/CCFE composites are summarized in Table 1. The maximum tensile strength of $702.72 \mathrm{~N} / \mathrm{mm}^{2}$ was observed for CCFE $0^{\circ}$ composites and the minimum tensile strength of $36.74 \mathrm{~N} / \mathrm{mm}^{2}$ for CCFE $45^{\circ}$ composites. The tensile properties of CNT/CCFE composites are depicted in graphical form in Figure 4.

Table 1. Tensile properties of CNT/CCFE composites

\begin{tabular}{cc}
\hline Sample ID & Tensile strength $\left(\mathbf{N} / \mathbf{m m}^{2}\right.$ \\
\hline CCFE $\left(0^{0}\right)_{4}$ & 702.72 \\
CCFE- $\left(0^{\circ} / 90^{\circ} / 0^{\circ} / 90^{\circ}\right)_{4}$ & 346.38 \\
CCFE $\left(45^{\circ}\right)_{4}$ & 36.74 \\
0.5 CNTCCFE $\left(0^{\circ} / 90^{\circ} / 0^{\circ} / 90^{\circ}\right)_{4}$ & 352.03 \\
1.5 CNTCCFE $\left(0^{\circ} / 90^{\circ} / 0^{\circ} / 90^{\circ}\right)_{4}$ & 577.65 \\
\hline
\end{tabular}

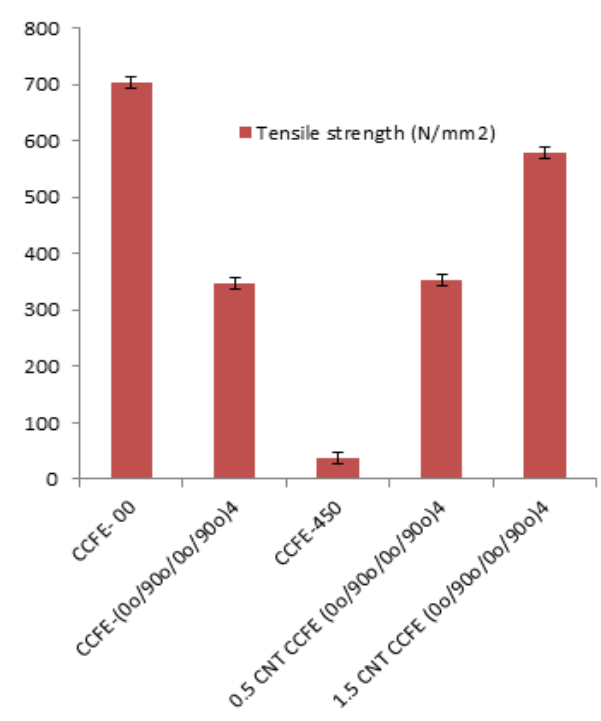

Figure 4. Tensile strength of CNT/CCFE composites

The orientation plays a major role in determining the tensile property of the material, it can be stated that $45^{\circ}$ oriented carbon fibre was forced to be alignedin the direction of load, but due to restriction by the epoxy resin there was a sudden failure of the fibre, that implies to a very least load withstanding capacity of the composite. The delamination between the plies results in least tensile strength [22].

The results infer that the tensile strength of $\mathrm{CCFE}-0^{\circ}$ composites was almost 50\% greater than $\operatorname{CCFE}\left(0^{\circ} / 90^{\circ} / 0^{\circ} / 90^{\circ}\right)_{4} \quad$ composites. $0.5 \quad$ CNT $\operatorname{CCFE}\left(0^{\circ} / 90^{\circ} / 0^{\circ} / 90^{\circ}\right)_{4}$ exhibited $1.63 \%$ increment in tensile strength when compared to $\operatorname{CCFE}\left(0^{\circ} / 90^{\circ} / 0^{\circ} / 90^{\circ}\right)_{4}$ composites. Increase in tensile strength was observed due to the better energy absorption of nanoparticles when subjected to load. 1.5 CNT $\operatorname{CCFE}\left(0^{\circ} / 90^{\circ} / 0^{\circ} / 90^{\circ}\right)_{4}$ composites showed $66.76 \%$ increment in tensile strength when compared with to $\operatorname{CCFE}\left(0^{\circ} / 90^{\circ} / 0^{\circ} / 90^{\circ}\right)_{4}$ composites. The substantial increment in tensile strength at $1.5 \mathrm{wt} \%$ of MWCNTs is because of the bonding of CNTs with epoxy matrix. In line with the above observation the better dispersion of the nanoparticles in the matrix and also the stress propagation were the reasons for increase in tensile strength [17].

\subsection{Compressive properties}

The Compressive strengths of CNT/CCFE composites were shown in Table 2. Graphical representation of compressive properties of CNT/CCFE composites is shown in Figure 5 $\mathrm{CCFE}\left(0^{0}\right)_{4}$ composites showed least compressive strength of $535.77 \mathrm{~N} / \mathrm{mm}^{2}$ and $\operatorname{CCFE}\left(0^{\circ} / 90^{\circ} / 0^{\circ} / 90^{\circ}\right)_{4}$ showed a high compressive strength of $2010.14 \mathrm{~N} / \mathrm{mm}^{2}$. Compressive strength of $\operatorname{CCFE}\left(0^{0}\right)_{4}$ composites were $275 \%$ lower than CCFE $\left(0^{\circ} / 90^{\circ} / 0^{\circ} / 90^{\circ}\right)_{4}$ composites. The fibres aligned both in horizontal and vertical directions in $\operatorname{CCFE}\left(0^{\circ} / 90^{\circ} / 0^{\circ} / 90^{\circ}\right)_{4}$ composites facilitate to withstand a maximum load of 90.026 $\mathrm{KN}$.

Table 2. Compressive properties of CNT/CCFE composites

\begin{tabular}{cc}
\hline Sample ID & $\begin{array}{c}\text { Compressive Strength } \\
\mathbf{N} / \mathbf{m m}^{2}\end{array}$ \\
\hline $\mathrm{CCFE}\left(0^{0}\right)_{4}$ & 535.77 \\
$\mathrm{CCFE}-\left(0^{\circ} / 90^{\circ} / 0^{\circ} / 90^{\circ}\right)_{4}$ & 2010.14 \\
$\mathrm{CCFE}\left(45^{\circ}\right)_{4}$ & 1054.177 \\
$0.5 \mathrm{CNT}$ & 2115.45 \\
$\mathrm{CCFE}\left(0^{\circ} / 90^{\circ} / 0^{\circ} / 90^{\circ}\right)_{4}$ & \\
$1.5 \mathrm{CNT}$ & 1795.67 \\
$\mathrm{CCFE}\left(0^{\circ} / 90^{\circ} / 0^{\circ} / 90^{\circ}\right)_{4}$ & \\
\hline
\end{tabular}

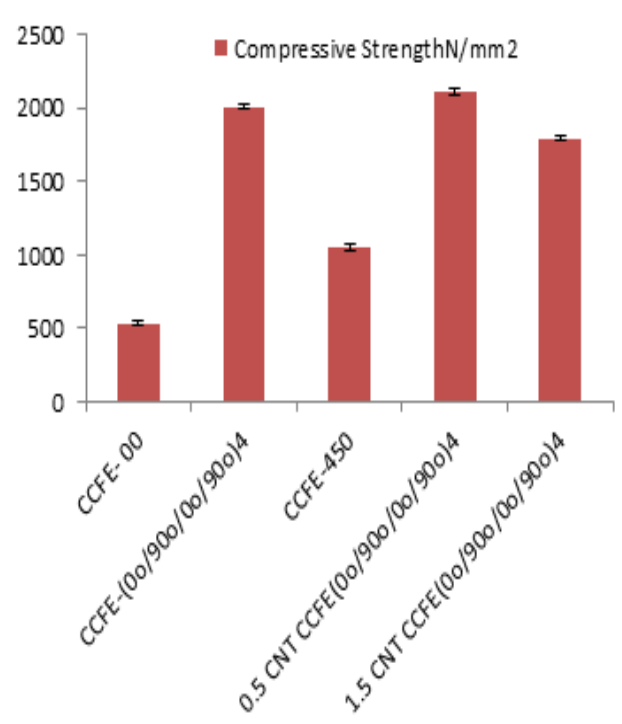

Figure 5. Compressive strength of CNT/CCFE composites 
Increment of $5.23 \%$ compressive strength was observed for $0.5 \mathrm{CNT} \operatorname{CCFE}\left(0^{\circ} / 90^{\circ} / 0^{\circ} / 90^{\circ}\right)_{4}$ when compared to $\mathrm{CCFE}\left(0^{\circ} / 90^{\circ} / 0^{\circ} / 90^{\circ}\right)_{4} \quad$ composites. $0.5 \quad \mathrm{CNT}$ $\mathrm{CCFE}\left(0^{\circ} / 90^{\circ} / 0^{\circ} / 90^{\circ}\right)_{4}$ exhibited maximum compressive strength of $2115.45 \mathrm{~N} / \mathrm{mm}^{2}$ and thereafter upon the addition of CNT at $1.5 \mathrm{wt} \%$, compressive strength was declined to $1795.67 \mathrm{~N} / \mathrm{mm}^{2}$ Because of the formation of CNT agglomerates which acted as stress concentration points. Also, deterioration of $10.66 \%$ in compressive strength at $1 \mathrm{wt} \%$ MWCNT was in tune with the other researchers [23].

\subsection{ILSS properties}

Table 3 depicts the interlaminar shear strength (ILSS) of $\mathrm{CNT/CCFE}$ composites and the graphical representation is shown in Figure 6. A maximum ILSS of $30.64 \mathrm{~N} / \mathrm{mm}^{2}$ was observed for $\operatorname{CCFE}\left(0^{0}\right)_{4}$ composites at a load of $1.88 \mathrm{KN}$. Interlaminar shear strength of $\operatorname{CCFE}\left(0^{\circ} / 90^{\circ} / 0^{\circ} / 90^{\circ}\right)_{4}$ and $\operatorname{CCFE}\left(45^{\circ}\right)_{4}$ composites were $89.3 \%$ and $84.75 \%$ lower than CCFE $\left(0^{\circ}\right)_{4}$ composites. This was due to the good bonding between lamina of same orientation.

Table 3. ILSS of CNT/CCFE composites

\begin{tabular}{cc}
\hline Sample ID & ILSS N/mm \\
\hline CCFE $\left(0^{\circ}\right)_{4}$ & 30.64 \\
CCFE- $\left(0^{\circ} / 90^{\circ} / 0^{\circ} / 90^{\circ}\right)_{4}$ & 3.25 \\
CCFE $\left(45^{\circ}\right)_{4}$ & 4.67 \\
0.5 CNT CCFE $\left(0^{\circ} / 90^{\circ} / 0^{\circ} / 90^{\circ}\right)_{4}$ & 24.42 \\
1.5 CNT CCFE $\left(0^{\circ} / 90^{\circ} / 0^{\circ} / 90^{\circ}\right)_{4}$ & 20.00 \\
\hline
\end{tabular}

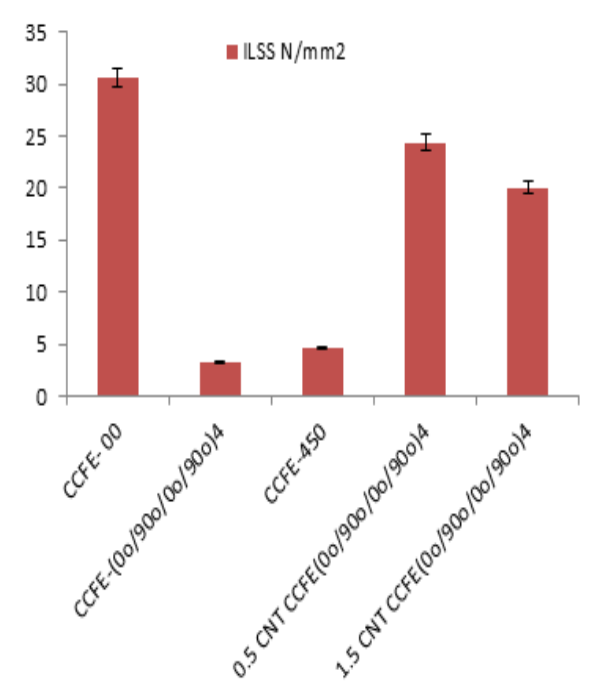

Figure 6. ILSS of CNT/CCFE composites

$0.5 \mathrm{CNT} \operatorname{CCFE}\left(0^{\circ} / 90^{\circ} / 0^{\circ} / 90^{\circ}\right)_{4}$ showed almost seven times greater ILSS when compared to $\operatorname{CCFE}\left(0^{\circ} / 90^{\circ} / 0^{\circ} / 90^{\circ}\right)_{4}$ composites. 1.5 CNT $\operatorname{CCFE}\left(0^{\circ} / 90^{\circ} / 0^{\circ} / 90^{\circ}\right)_{4}$ composites exhibited almost six times higher ILSS when compared to $\operatorname{CCFE}\left(0^{\circ} / 90^{\circ} / 0^{\circ} / 90^{\circ}\right)_{4}$ composites. This increment in ILSS was due to good penetration of nanoparticles in to the lamina [19, 24].

\subsection{Flexural properties}

The flexural properties of CNT/CCFE composites were summarized in Table 4 and the same is depicted in graphical form in Figure 7. The Flexural strength for CCFE $0^{\circ}$ composites was greater when compared to other orientations, because of uniform distribution of load in axial direction among the fibres. A deterioration of $36 \%$ was observed in the flexural strength of $0.5 \mathrm{CNT} \operatorname{CCFE}\left(0^{\circ} / 90^{\circ} / 0^{\circ} / 90^{\circ}\right)_{4}$ when compared to $\operatorname{CCFE}\left(0^{\circ} / 90^{\circ} / 0^{\circ} / 90^{\circ}\right)_{4}$ composites due to the increase in resin viscosity because of CNTs, which there by resulted in poor impregnation of carbon fibres.In contrary to the above observation, the flexural strength of multistate composites increase by $24.69 \%$ and $38.04 \%$ up on the incorporation of $0.5 \mathrm{wt} \%$ and $1 \mathrm{wt} \%$ MWCNTs [24]

Table 4. Flexural properties of CNT/CCFE composites

\begin{tabular}{cc}
\hline Sample ID & Flexural Strength N/mm $\mathbf{m}^{\mathbf{2}}$ \\
\hline $\mathrm{CCFE}\left(0^{\circ}\right)_{4}$ & 658.49 \\
$\mathrm{CCFE}-\left(0^{\circ} / 90^{\circ} / 0^{\circ} / 90^{\circ}\right)_{4}$ & 503.45 \\
$\mathrm{CCFE}\left(45^{\circ}\right)_{4}$ & 76.21 \\
$0.5 \mathrm{CNT} \mathrm{CCFE}\left(0^{\circ} / 90^{\circ} / 0^{\circ} / 90^{\circ}\right)_{4}$ & 317.34 \\
$1.5 \mathrm{CNT} \mathrm{CCFE}\left(0^{\circ} / 90^{\circ} / 0^{\circ} / 90^{\circ}\right)_{4}$ & 469.11 \\
\hline
\end{tabular}

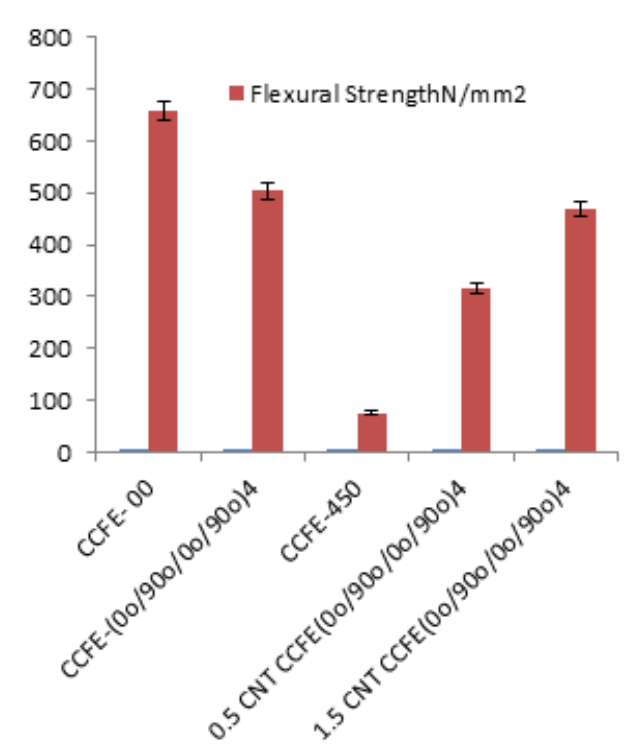

Figure 7. Flexural properties of CNT/CCFE composites

\subsection{Hardness}

Table 5 indicates the hardness values of CNT/CCFE composites and graphically represented in Figure 8. From the results it was evident that there was only $3.9 \%$ increment in the hardness of $0.5 \mathrm{CNT} \operatorname{CCFE}\left(0^{\circ} / 90^{\circ} / 0^{\circ} / 90^{\circ}\right)_{4}$ when compared to $\operatorname{CCFE}\left(0^{\circ} / 90^{\circ} / 0^{\circ} / 90^{\circ}\right)_{4}$ composites. Also there is $3.91 \%$ decrement in the hardness of 1.5 CNT $\operatorname{CCFE}\left(0^{\circ} / 90^{\circ} / 0^{\circ} / 90^{\circ}\right)_{4}$ composites. This clearly indicates that the hardness of CCFE composites decreases at higher percentages of MWCNTs which is due to the clustering of CNTs which inturn reduces the efficiency of Nano reinforcement.

Table 5. Hardness of CNT/CCFE composites

\begin{tabular}{cc}
\hline Sample ID & Hardness \\
\hline CCFE $\left(0^{0}\right)_{4}$ & 86.67 \\
CCFE- $\left(0^{\circ} / 90^{\circ} / 0^{\circ} / 90^{\circ}\right)_{4}$ & 85.00 \\
CCFE $\left(45^{\circ}\right)_{4}$ & 86.67 \\
0.5 CNT CCFE $\left(0^{\circ} / 90^{\circ} / 0^{\circ} / 90^{\circ}\right)_{4}$ & 88.33 \\
1.5 CNT CCFE $\left(0^{\circ} / 90^{\circ} / 0^{\circ} / 90^{\circ}\right)_{4}$ & 81.67 \\
\hline
\end{tabular}




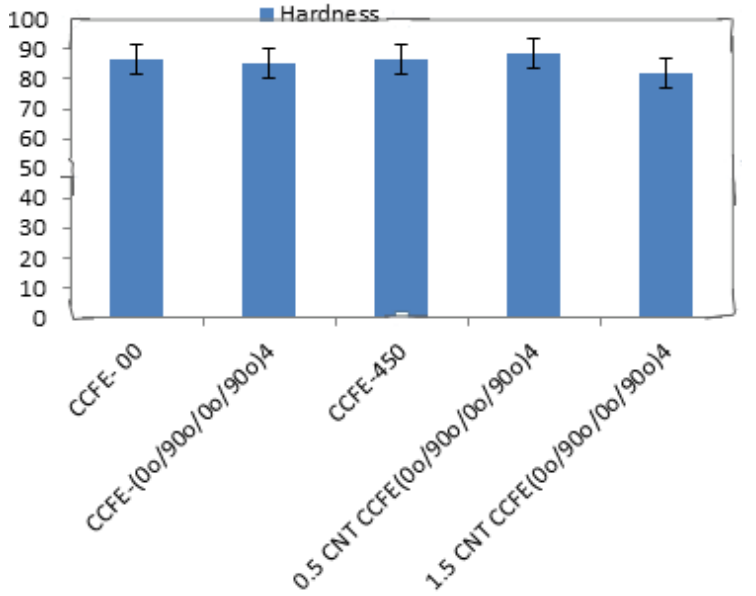

Figure 8. Hardness of CNT/CCFE composites

\subsection{Impact test}

Table 6. Impact strength of CNT/CCFE composites

\begin{tabular}{lc}
\hline \multicolumn{1}{c}{ Sample ID } & Impact Strength KJ/m \\
\hline CCFE- $\left(0^{\circ}\right)_{4}$ & 74.765 \\
CCFE- $\left(0^{\circ} / 90^{\circ} / 0^{\circ} / 90^{\circ}\right)_{4}$ & 45.661 \\
CCFE $\left(45^{\circ}\right)_{4}$ & 23.909 \\
$0.5 \mathrm{CNT} \mathrm{CCFE}\left(0^{\circ} / 90^{\circ} / 0^{\circ} / 90^{\circ}\right)_{4}$ & 53.182 \\
$1.5 \mathrm{CNT}$ CCFE $\left(0^{\circ} / 90^{\circ} / 0^{\circ} / 90^{\circ}\right)_{4}$ & 75.473 \\
\hline
\end{tabular}

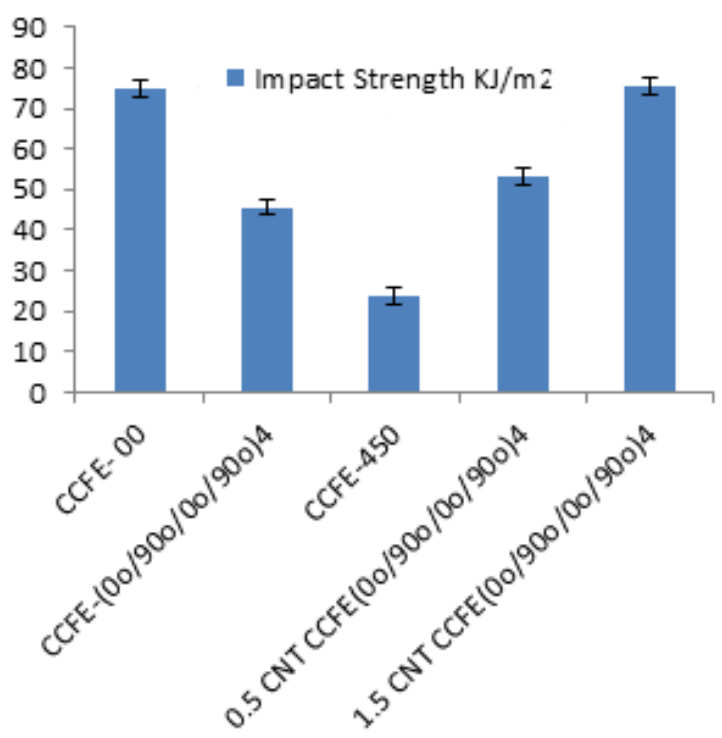

Figure 9. Impact strength of CNT/CCFE composites

The higher impact strength of $74.765 \mathrm{KJ} . \mathrm{m}^{2}$ was observed for CCFE $\left(0^{0}\right)_{4}$ composites when compared to other composites from Table 6 . The impact strengths of CNT/CCFE composites were depicted in graphical form in Figure 9. $\operatorname{CCFE}\left(0^{\circ} / 90^{\circ} / 0^{\circ} / 90^{\circ}\right)_{4}$ composites when subjected to impact load exhibit lower impact strength due to the load shearing by fibres in longitudinal and lateral direction simultaneously.

$0.5 \mathrm{CNT} \operatorname{CCFE}\left(0^{\circ} / 90^{\circ} / 0^{\circ} / 90^{\circ}\right)_{4}$ showed $16.47 \%$ increment in impact strength when compared to $\operatorname{CCFE}\left(0^{\circ} / 90^{\circ} / 0^{\circ} / 90^{\circ}\right)_{4}$ composites. $1.5 \mathrm{CNT} \operatorname{CCFE}\left(0^{\circ} / 90^{\circ} / 0^{\circ} / 90^{\circ}\right)_{4}$ composites exhibited $39.53 \%$ increment in impact strength when compared with to $\operatorname{CCFE}\left(0^{\circ} / 90^{\circ} / 0^{\circ} / 90^{\circ}\right)_{4}$ composites. This increment in impact strength was due to the higher energy absorption by CNTs which results in minor delamination [25].

\subsection{Water absorption}

The water absorption of CNT/CCFE composites is shown in Table 7. Results indicate the negligible water absorption of $\mathrm{CCF} / \mathrm{CNT}$ composites. $0.5 \mathrm{CNT} \operatorname{CCFE}\left(0^{\circ} / 90^{\circ} / 0^{\circ} / 90^{\circ}\right)_{4}$ showed $29.6 \%$ increment in water absorption when compared to $\mathrm{CCFE}\left(0^{\circ} / 90^{\circ} / 0^{\circ} / 90^{\circ}\right)_{4}$ composites.

Table 7. Water absorption of CNT/CCFE composites

\begin{tabular}{cc}
\hline Sample Name & Water absorption \% \\
\hline CCFE- $\left(0^{0}\right)_{4}$ & $\mathbf{0 . 2 0}$ \\
CCFE- $\left(0^{\circ} / 90^{\circ} / 0^{\circ} / 90^{\circ}\right)_{4}$ & $\mathbf{0 . 2 7}$ \\
CCFE $\left(45^{\circ}\right)_{4}$ & $\mathbf{0 . 0 7}$ \\
0.5 CNTCCFE $\left(0^{\circ} / 90^{\circ} / 0^{\circ} / 90^{\circ}\right)_{4}$ & $\mathbf{0 . 3 5}$ \\
1.5 CNT CCFE $\left(0^{\circ} / 90^{\circ} / 0^{\circ} / 90^{\circ}\right)_{4}$ & $\mathbf{0 . 3 0}$ \\
\hline
\end{tabular}

\section{CONCLUSIONS}

The present study reported the fabrication method and influence of MWCNTs content on the mechanical properties ofCCFE $\left(0^{\circ} / 90^{\circ} / 0^{\circ} / 90^{\circ}\right)_{4}$ composites. The experimental conclusions were as follows:

- The tensile strength of $0.5 \operatorname{CNT} \operatorname{CCFE}\left(0^{\circ} / 90^{\circ} / 0^{\circ} / 90^{\circ}\right)_{4}$ exhibited $1.63 \%$ increment in tensile strength when compared to $\operatorname{CCFE}\left(0^{\circ} / 90^{\circ} / 0^{\circ} / 90^{\circ}\right)_{4}$ composites.

- $\quad 0.5 \mathrm{CNT} \operatorname{CCFE}\left(0^{\circ} / 90^{\circ} / 0^{\circ} / 90^{\circ}\right)_{4}$ exhibited maximum compressive strength of $2115.45 \mathrm{~N} / \mathrm{mm}^{2}$ and thereafter upon the addition of CNT at $1.5 \mathrm{wt} \%$, compressive strength was declined to 1795.67 $\mathrm{N} / \mathrm{mm}^{2}$.

- $\quad 0.5 \mathrm{CNT} \operatorname{CCFE}\left(0^{\circ} / 90^{\circ} / 0^{\circ} / 90^{\circ}\right)_{4}$ showed almost seven times incremental ILSS when compared to $\operatorname{CCFE}\left(0^{\circ} / 90^{\circ} / 0^{\circ} / 90^{\circ}\right)_{4} \quad$ composites. $1.5 \quad \mathrm{CNT}$ $\operatorname{CCFE}\left(0^{\circ} / 90^{\circ} / 0^{\circ} / 90^{\circ}\right)_{4}$ composites exhibited six times higher ILSS when compared to $\operatorname{CCFE}\left(0^{\circ} / 90^{\circ} / 0^{\circ} / 90^{\circ}\right)_{4}$ composites.

- A deterioration of $36 \%$ was observed in the flexural strength of $0.5 \mathrm{CNT} \operatorname{CCFE}\left(0^{\circ} / 90^{\circ} / 0^{\circ} / 90^{\circ}\right)_{4}$ when compared to $\mathrm{CCFE}\left(0^{\circ} / 90^{\circ} / 0^{\circ} / 90^{\circ}\right)_{4}$ composites.

- There is only $3.9 \%$ increment in the hardness of 0.5 $\mathrm{CNT} \operatorname{CCFE}\left(0^{\circ} / 90^{\circ} / 0^{\circ} / 90^{\circ}\right)_{4}$ when compared to $\operatorname{CCFE}\left(0^{\circ} / 90^{\circ} / 0^{\circ} / 90^{\circ}\right)_{4}$ composites. Also, there is $3.91 \%$ decrement in the hardness of 1.5 CNT $\operatorname{CCFE}\left(0^{\circ} / 90^{\circ} / 0^{\circ} / 90^{\circ}\right)_{4}$ composites.

- $0.5 \mathrm{CNT} \quad \mathrm{CCFE}\left(0^{\circ} / 90^{\circ} / 0^{\circ} / 90^{\circ}\right)_{4}, 1.5 \quad \mathrm{CNT}$ $\mathrm{CCFE}\left(0^{\circ} / 90^{\circ} / 0^{\circ} / 90^{\circ}\right)_{4}$ composites exhibited $16.47 \%$, $39.53 \%$ increment in impact strength when compared to $\operatorname{CCFE}\left(0^{\circ} / 90^{\circ} / 0^{\circ} / 90^{\circ}\right)_{4}$ composites.

- $\quad 0.5 \mathrm{CNT} \operatorname{CCFE}\left(0^{\circ} / 90^{\circ} / 0^{\circ} / 90^{\circ}\right)_{4}$ showed $29.6 \%$ increment in water absorption when compared to $\operatorname{CCFE}\left(0^{\circ} / 90^{\circ} / 0^{\circ} / 90^{\circ}\right)_{4}$ composites.

The future scope of the work is treatment of CNTs with Nitric acid to improve the adhesion properties when reinforced in the composite.

\section{REFERENCES}

[1] Botelho, E.C., Silva, R.A., Pardini, L.C., Rezende, M.C. (2006). A review on the development and properties of continuous fiber/epoxy/aluminum hybrid composites for aircraft structures. Materials Research, 9(3): 247-256. 
http://dx.doi.org/10.1590/S1516-14392006000300002

[2] Li, M., Gu, Y.Z., Liu, H., Li, Y.X., Wang, S.K., Wu, Q., Zhang, Z.G. (2013). Investigation the interphase formation process of carbon fiber/epoxy composites using a multiscale simulation method. Composites Science and Technology, 86: 117-121. http://dx.doi.org/10.1016/j.compscitech.2013.07.008

[3] Zhang, Q.J., Liang, S.B., Sui, G., Yang, X.P. (2015). Influence of matrix modulus on the mechanical and interfacial properties of carbon fiber filament wound composites. Rsc Advances, 5(32): 25208-25214. http://dx.doi.org/10.1039/C5RA00098J

[4] Qian, H., Bismarck, A., Greenhalgh, E.S., Shaffer, M.S. (2010). Carbon nanotube grafted carbon fibres: A study of wetting and fibre fragmentation. Composites Part A: Applied Science and Manufacturing, 41(9): 1107-1114. http://dx.doi.org/10.1016/j.compositesa.2010.04.004

[5] Warrier, A., Godara, A., Rochez, O., Mezzo, L., Luizi, F., Gorbatikh, L., Verpoest, I. (2010). The effect of adding carbon nanotubes to glass/epoxy composites in the fibre sizing and/or the matrix. Composites Part A: Applied Science and Manufacturing, 41(4): 532-538. http://dx.doi.org/10.1016/j.compositesa.2010.01.001

[6] Guo, Y.Q., Xu, G.J., Yang, X.T., Ruan, K.P., Ma, T.B., Zhang, Q.Y., Gu, J.W., Wu, Y.L., Liu, H., Guo, Z.H. (2018). Significantly enhanced and precisely modeled thermal conductivity in polyimide nanocomposites with chemically modified graphene via in situ polymerization and electrospinning-hot press technology. Journal of Materials Chemistry C, 6(12): 3004-3015. http://dx.doi.org/10.1039/C8TC00452H

[7] Li, Y.H., Zhou, B., Zheng, G.Q., Liu, X.H., Li, T.X., Yan, C., Cheng, C.B., Dai, K., Liu, C.T., Shen, C.Y., Guo, Z.H. (2018). Continuously prepared highly conductive and stretchable SWNT/MWNT synergistically composited electrospun thermoplastic polyurethane yarns for wearable sensing. Journal of Materials Chemistry C, 6(9): 2258-2269. http://dx.doi.org/10.1039/C7TC04959E

[8] Sun, K., Xie, P.T., Wang, Z.Y., Su, T.M., Shao, Q., Ryu, J.E., Zhang, X.H., Guo, J., Shankar, A., Li, J.F., Fan, R.H., Cao, D.P., Guo, Z.H. (2017). Flexible polydimethylsiloxane/multi-walled carbon nanotubes membranous metacomposites with negative permittivity. Polymer, 125: 50-57. http://dx.doi.org/10.1016/j.polymer.2017.07.083

[9] Guo, J., Song, H.X., Liu, H., Luo, C.J., Ren, Y.R., Ding, T., Khan, M.A., Young, D.P., Liu, X.Y., Zhang, X., Kong, J., Guo, Z.H. (2017). Polypyrrole-interfacefunctionalized nano-magnetite epoxy nanocomposites as electromagnetic wave absorbers with enhanced flame retardancy. Journal of Materials Chemistry C, 5(22): 5334-5344.

http://dx.doi.org/10.1016/j.polymer.2017.07.083

[10] Wang, Z.C., Wei, R.B., Gu, J.W., Liu, H., Liu, C.T., Luo, C.J., Kong, J., Shao, Q., Wang, N., Guo, Z.H., Liu, X.B. (2018). Ultralight, highly compressible and fire-retardant graphene aerogel with self-adjustable electromagnetic wave absorption. Carbon, 139: 1126-1135. http://dx.doi.org/10.1016/j.carbon.2018.08.014

[11] Li, Y.Y., Jing, T., Xu, G.F., Tian, J.Z., Dong, M.Y., Shao, Q., Wang, B., Wang, Z.K., Zheng, Y.J., Yang, C.L., Guo, Z.H. (2018). 3-D magnetic graphene oxide-magnetite poly (vinyl alcohol) nanocomposite immobilizing enzyme.

Polymer,

149:

$13-22$ http://dx.doi.org/10.1016/j.carbon.2018.08.014

[12] Hu, C., Li, Z.Y., Wang, Y.L., Gao, J.C., Dai, K., Zheng, G.Q., Liu, C.T., Shen, C.Y., Song, H.X., Guo, Z.H. (2017). Comparative assessment of the strain-sensing behaviors of polylactic acid nanocomposites: Reduced graphene oxide or carbon nanotubes. Journal of Materials Chemistry $\quad$ C, 5(9): 2318-2328. http://dx.doi.org/10.1039/C6TC05261D

[13] Mei, H., Zhang, S.M., Chen, H., Zhou, H.S., Zhai, X.Y., Cheng, L.F. (2016). Interfacial modification and enhancement of toughening mechanisms in epoxy composites with CNTs grafted on carbon fibers. Composites Science and Technology, 134: 89-95. http://dx.doi.org/10.1016/j.compscitech.2016.08.010

[14] Pozegic, T.R., Jayawardena, K.D.G.I., Chen, J.S., Anguita, J.V., Ballocchi, P., Stolojan, V., Hamerton, I. (2016). Development of sizing-free multi-functional carbon fibre nanocomposites. Composites Part A: Applied Science and Manufacturing, 90: 306-319. http://dx.doi.org/10.1016/j.compositesa.2016.07.012

[15] Jones, F.R. (2010). A review of interphase formation and design in fibre-reinforced composites. Journal of Adhesion Science and Technology, 24(1): 171-202. http://dx.doi.org/10.1163/016942409X12579497420609

[16] Lv, P., Feng, Y.Y., Zhang, P., Chen, H.M., Zhao, N., Feng, W. (2011). Increasing the interfacial strength in carbon fiber/epoxy composites by controlling the orientation and length of carbon nanotubes grown on the fibers. Carbon, 49(14): 4665-4673. http://dx.doi.org/10.1016/j.carbon.2011.06.064

[17] Siddiqui, N.A., Khan, S.U., Kim, J.K. (2013). Experimental torsional shear properties of carbon fiber reinforced epoxy composites containing carbon nanotubes. Composite Structures, 104: 230-238. http://dx.doi.org/10.1016/j.compstruct.2013.04.033

[18] Pathak, A.K., Borah, M., Gupta, A., Yokozeki, T., Dhakate, S.R. (2016). Improved mechanical properties of carbon fiber/graphene oxide-epoxy hybrid composites. Composites Science and Technology, 135: 28-38. http://dx.doi.org/10.1016/j.compscitech.2016.09.007

[19] Han, S., Chung, D.D.L. (2013). Strengthening and stiffening carbon fiber epoxy composites by halloysite nanotubes, carbon nanotubes and silicon carbide whiskers. Applied Clay Science, 83-84: 375-382. http://dx.doi.org/10.1016/j.clay.2013.08.001

[20] Chen, X., Xu, H., Liu, D., Yan, C., Zhu, Y. (2019). A novel and facile fabrication of polyphosphazene nanotube/carbon fiber multi-scale hybrid reinforcement and its enhancing effect on the interfacial properties of epoxy composites. Composites Science and Technology, 169: 34-44. https://doi.org/10.1016/j.compscitech.2018.10.034

[21] Bortz, D.R., Merino, C., Martin-Gullon, I. (2012). Augmented fatigue performance and constant life diagrams of hierarchical carbon fiber/nanofiber epoxy composites. Composites Science and Technology, 72(3): 446-452.

http://dx.doi.org/10.1016/j.compscitech.2011.12.006

[22] Liang, Y., Wang, H., Gu, X.S. (2013). In-plane shear response of unidirectional fiber reinforced and fabric reinforced carbon/epoxy composites. Polymer Testing, 32(3): 594-601. http://dx.doi.org/10.1016/j.polymertesting.2013.01.015

[23] Liao, Y.H., Marietta-Tondin, O., Liang, Z., Zhang, C., 
Wang, B. (2004). Investigation of the dispersion process of SWNTs/SC-15 epoxy resin nanocomposites. Materials Science and Engineering: A, 385(1-2): 175181. http://dx.doi.org/10.1016/S0921-5093(04)00857-3

[24] Sharma, K., Shukla, M. (2014). Three-phase carbon fiber amine functionalized carbon nanotubes epoxy composite: processing, characterisation, and multiscale modelling. Journal
Nanomaterials, http://dx.doi.org/10.1155/2014/837492

[25] Kostopoulos, V., Baltopoulos, A., Karapappas, P., Vavouliotis, A., Paipetis, A. (2010). Impact and afterimpact properties of carbon fibre reinforced composites enhanced with multi-wall carbon nanotubes. Composites Science and Technology, 70(4): 553-563. http://dx.doi.org/10.1016/j.compscitech.2009.11.023 